doi: $10.15330 /$ msuc.2020.23.9-13

\author{
Тетяна Котик, \\ доктор педагогічних наук, \\ професор кафедри фахових методик і технологій \\ початкової освіти, \\ ДВНЗ «Прикарпатський національний університет \\ імені Василя Стефаника» \\ (м. Івано-Франківськ, Україна)
}

\author{
Tetiana Kotyk, \\ Doctor of Pedagogical Sciences, Professor, \\ Department of Professional Methods \\ and Technologies of Primary Education, \\ Vasyl Stefanyk Precarpathian National University \\ (Ivano-Frankivsk, Ukraine) \\ tetiana.m.kotyk@pu.if.ua \\ ORCID ID 0000-0001-8213-8318
}

УДК 37.047:81’246.2

\title{
ЕМОЦІЙНИЙ ІНТЕЛЕКТ УЧИТЕЛІВ ПОЧАТКОВОЇ ШКОЛИ
}

\begin{abstract}
Анотація. Переорієнтація сучасної української школи із знаннєвої на компетентнісну має на меті формування в учнів життєвого досвіду, необхідних знань, умінь та цінностей, важливих для успішної реалізації в швидкозмінюваному суспільстві.

Концепція Нової української школи проголошує особистісно зорієнтоване навчання, тобто орієнтоване не на звичайне засвоєння знань, а на формування особистості самої дитини, їі характеру, ставлення до світу. Мета модернізації системи освіти - переведення вектора пізнання із зовнішнього світу дитини, створеного природою та людиною, на засвоєння процесів взаємодії з цим світом, розуміння смислів власної діяльності.

Відтак особливої актуальності набуває наукове обґрунтування процесу підготовки вчителів до реалізації завдань Нової української школи, зокрема в аспекті розвитку такої особистісної якості учнів, як емоційний інтелект. У статті розкрито сутність емоційного інтелекту як психолого-педагогічного феномену, вимоги до емоційного інтелекту вчителів початкової школи та особливості його розвитку в сучасних учителів. Висвітлено різні дефініції поняття «емоційний інтелект» та узагальнено його сутність і структуру відповідно до професійної діяльності вчителя молодших класів, визначено емоційні складові професійних компетентностей учителя початкової школи. Висвітлено результати аналізу професійного стандарту «Учитель початкових класів закладу загальної середньої освіти» та Типової освітньої програми для підвищення кваліфікації педагогічних працівників щодо самоосвіти вчителів з розвитку емоційного інтелекту самих педагогів. Дійшли висновку, що обов'язковою трудовою функцією вчителя $€$ необхідність самооцінювання й визначення сильних і слабких сторін власної педагогічної діяльності, у тому числі її емоційної складової. Зважаючи на такий висновок, звернулися до праць психологів, в яких висвітлено особливості емоційного інтелекту сучасних учителів початкової школи. Було встановлено, що більшість учителів не розуміють емоцій інших людей за зовнішніми проявами та відчувають значні труднощі в керуванні власними емоціями, дуже песимістично оцінюють власні можливості впливати на емоційні стани учнів та їх змінювати. Найбільш проблемними компонентами власного емоційного інтелекту вчителі визнали здатність, а точніше нездатність, керувати власними емоціями, невміння здійснювати емоційну саморегуляцію. Проаналізовано та узагальнено думки психологів щодо моделі емоційного інтелекту педагога, на основі чого дійшли висновку, що незважаючи на розбіжності в трактуванні змісту та компонентів емоційного інтелекту вчителів, науковці спільні в думці про те, що це інтегроване динамічне утворення, структуру якого складають емоційний, когнітивний та діяльнісний компоненти, які в єдності забезпечують вимоги педагогічної професії, її гуманістичної сутності. Відтак, встановили значущість для педагогічної діяльності вчителів початкової школи таких особистісних якостей і складових емоційного інтелекту, як емпатія, здатність до саморегуляції, комунікативність.
\end{abstract}

Ключові слова: Нова українська школа, емоційний інтелект, вчителі початкової школи, складові емоційного інтелекту вчителів початкової школи.

\section{EMOTIONAL INTELLIGENCE OF PRIMARY SCHOOL TEACHERS}

Abstract. The reorientation of the modern Ukrainian school from knowledge to competence is aimed at forming in students' life experience, necessary knowledge, skills and values important for successful implementation in a rapidly changing society. The concept of the New Ukrainian School proclaims personality-oriented learning, which is focused not on the usual acquisition of knowledge, but on the formation of the child's personality, his character, and attitude to the world. The purpose of modernizing the education system is to transfer the vector of knowledge from the external world of the child, created by nature and man, to master the processes of interaction with this world, understanding the meanings of their own activities. Therefore, the scientific substantiation of the process of preparing teachers for the implementation of the tasks of the New Ukrainian School, in particular in the aspect of the development of such a personal quality of students as emotional 
intelligence, becomes especially relevant. The article reveals the essence of emotional intelligence as a psychological and pedagogical phenomenon, the requirements for emotional intelligence of primary school teachers and the peculiarities of its development in modern teachers. Different definitions of the concept of "emotional intelligence" are highlighted and its essence and structure are generalized in accordance with the professional activity of a primary school teacher, the emotional components of professional competencies of a primary school teacher are determined. The results of the analysis of the professional standard "Primary school teacher of general secondary education" and the Standard educational program for professional development of teachers in self-education of teachers for the development of emotional intelligence of teachers are presented. It was concluded that the obligatory work function of a teacher is the need to self-assess and identify the strengths and weaknesses of their own pedagogical activities, including its emotional component.

Keywords: New Ukrainian School, emotional intelligence, primary school teachers, components of emotional intelligence of primary school teachers.

\section{ВСТУП}

Постановка проблеми. У Державному стандарті загальної початкової освіти визначено змістові орієнтири для цілісного розвитку особистості учня початкової школи і сформульовано їх як наскрізні уміння, що $€$ загальними для всіх освітніх галузей і обов'язковими для формування в учнів, а саме: розв'язує проблеми, критично та творчо мислить, співпрацює, ефективно спілкується, розвиває власний емоційний інтелект, досліджує, організовує свою діяльність, рефлексує, читає вдумливо. Такі орієнтири відображають збалансовану взаємодію основних структурних компонентів особистості: емоційного («Відчуваю»), мисленнєвого («Думаю») та діяльнісного («Дію»).

Отже, завдання з розвитку емоційного інтелекту є важливим компонентом змісту початкової освіти. Оволодіння ним учнями початкової школи як засобом успішної суспільної взаємодії та пізнання себе та інших має стати найважливішим надбанням дитини в молодшому шкільному віці, що вирізняється особливою сенситивністю до засвоєння норм і правил суспільної комунікації.

Ефективність роботи з розвитку емоційного інтелекту залежить від чітко продуманої системи педагогічного впливу, емоційної компетентності самого вчителя. На педагогічних факультетах така підготовка ще не здійснюється, тому за допомогою самоосвіти кожен учитель зможе опанувати основи теорії емоційного інтелекту, зрозуміти його сутність, структуру, вплив на поведінку та здоров'я людини, зорієнтуватися в колі фахової літератури з проблеми формування емоційного інтелекту в початковій школі, виборі необхідного дидактичного матеріалу, рефлексивно осмислити роль емоційного інтелекту в житті молодших школярів та у власній життєдіяльності.

Аналіз наукових досліджень і публікацій. На початку XXI ст. почала активно розвиватися позитивна, або популярна психологія, що досліджує засади виникнення та існування щастя в людини, лідером напрацювань у якій є Д. Гоулман (Гоулман Д., 2018). Академічна психологія також визнає важливість дослідження цього феномену, що має високий пояснювальний та прогностичний потенціал для пізнання поведінки та подальшого життя особистості. Відтак інтерес до теорії емоційного інтелекту почав швидко зростати. У популярній літературі емоційний інтелект визначається по-різному, розкриваються методики його швидкого розвитку, висвітлюється його роль у безсумнівному успіху в житті. Зарубіжні та вітчизняні науковці наполегливо досліджують особливості цього наукового феномену в людей різного віку й різних професій та шукають способи його розвитку й вимірювання, пропонують варіанти удосконалення загальної концепції та структури емоційного інтелекту. Результати цих досліджень висвітлюють у наукових працях та науково-популярних виданнях, створюють рекомендації, програми та тренінги з його розвитку.

Наразі глибокі й системні дослідження емоційного інтелекту ще попереду.

Емоційний інтелект - поняття ще дуже молоде для науки й малодосліджене, науковці ще в пошуку його точного визначення та більш правильної назви: вагаються щодо правомірності об'єднувати в одному терміні почуття та інтелект; щодо можливості віднесення до його компонентів інших характеристик особистості, крім емоційних; не впевнені в тому, що це взагалі інтелектуальна здібність. До прикладу, наведемо декілька визначень емоційного інтелекту, зроблених зарубіжними та вітчизняними дослідниками:

- уміння «інтелектуально» керувати своїм емоційним життям (Х. Вайсбах і У. Дакс (Вайсбах Х., Дакс У., 1998));

- емоційно-інтелектуальна діяльність (Є. Ільїн (Ильин Е., 2017));

- особлива форма організації індивідуального емоційного досвіду у вигляді наявних емоційних структур, що породжують емоційний простір відображення й емоційні репрезентації, які будуються в межах цього простору (М. Журавльова (Журавльова М., без дати));

- інтегральна властивість особистості, яка відображає пізнавальну здатність людини до розуміння емоцій та управління ними шляхом когнітивної обробки емоційної інформації, і забезпечує психологічне благополуччя особистості та успішність соціальної взаємодії (М. Шпак (Шпак М., 2011));

- інтегративна особистісна властивість, яка зумовлюється динамічною єдністю афекту та інтелекту через взаємодію емоційних, когнітивних, конативних і мотиваційних особливостей і спрямована на розуміння власних емоцій та емоційних переживань інших, забезпечує управління емоційним станом, підпорядкування емоцій розуму, сприяє самопізнанню і самореалізації через збагачення емоційного і соціального досвіду (М. Шпак (Шпак М., 2017)); 
• здібності до розуміння своїх і чужих емоцій та керування ними (Д. Люсин (Люсин Д., 1996));

- здатність розуміти ставлення особистості, репрезентовані в емоціях, та керувати емоційною сферою на основі інтелектуального аналізу і синтезу (Г. Гарскова (Гарскова Г., 1999)).

- здібність адекватно сприймати, оцінювати та виражати емоції; спроможність породжувати почуття, коли вони сприяють мисленню; спроможність розуміти емоції та знання, що стосуються емоцій, а також здібність регулювати емоції, щоб сприяти власному емоційному та інтелектуальному зростанню (П. Селовей та Дж. Меєр (Mayer, Salovey, 1993)).

\section{МЕТА I ЗАВДАННЯ ДОСЛІДЖЕННЯ}

Мета нашого дослідження - допомогти вчителям початкової школи сформувати узагальнене уявлення про емоційний інтелект як психолого-педагогічний феномен та визначити ті елементи емоційного інтелекту, які $€$ базисними для розвитку професійних компетентностей учителів початкової школи.

\section{МЕТОДИ ДОСЛІДЖЕННЯ}

У процесі дослідження використано методи теоретичного аналізу, узагальнення, конкретизації матеріалів джерельної бази дослідження.

\section{РЕЗУЛЬТАТИ ДОСЛІДЖЕННЯ}

- професійно-педагогічну,

- соціально-громадянську,

- загальнокультурну,

- мовно-комунікативну,

- психологічно-фасилітативну,

- підприємницьку,

- інформаційно-цифрову,

компонентами яких є такі складові емоційного інтелекту, як (див. рис. 1):

- уміння визначати проблеми та віднаходити способи їх вирішення,

- уміння вислуховувати інших та обстоювати власну думку,

- уміння попереджувати та розв'язувати конфлікти,

- здатність до ефективної командної роботи,

- продуктивна комунікативна взаємодія,

- культура професійного спілкування, педагогічний такт,

- уміння виражати почуття за допомогою мистецтва,

- розвинена педагогічна рефлексія,

- здатність сформувати самосвідомість у кожного учня та ставитися до його психо-емоційного здоров'я як до цінності (Типова освітня програма, 2018).

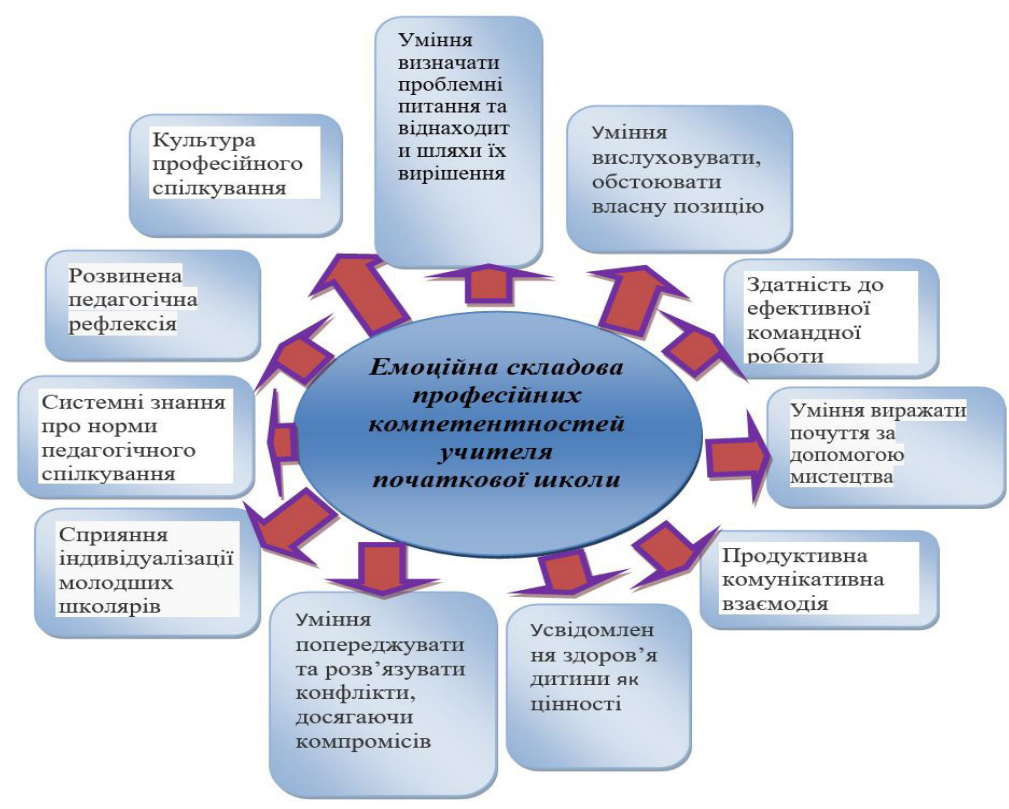

Рис. 1. Емоційна складова професійних компетентностей учителя початкової школи

Натомість у змістовому аспекті Типової освітньої програми для підвищення кваліфікації педагогічних працівників не передбачено роботу з розвитку емоційного інтелекту самих вчителів. Але в професійному стандарті «Учитель початкових класів закладу загальної середньої освіти» (Професійний стандарт, без дати) передбачено таку обов'язкову трудову функцію вчителя, як «Рефлексія та професійний саморозвиток», що зумовлює необхідність 
самооцінювання й визначення сильних і слабких сторін власної педагогічної діяльності, у тому числі її емоційної складової, та усвідомлення потреби в саморозвитку задля набуття необхідних професійних компетентностей.

Розглянемо особливості емоційного інтелекту сучасних учителів початкової школи. За даними дослідження О. Новак, лише незначний відсоток учителів (16\%) володіють високим рівнем емоційного інтелекту, а більше третини ïx (38\%) - мають низький його рівень, що було визначено за даними самооцінювання педагогів за методикою Н. Холла. Було з'ясовано, що більшість учителів не розуміють емоцій інших людей за зовнішніми проявами та відчувають значні труднощі в керуванні власними емоціями, дуже песимістично оцінюють власні можливості впливати на емоційні стани учнів та їх змінювати. Найбільш проблемними компонентами власного емоційного інтелекту вчителі визнали здатність, а точніше нездатність, керувати власними емоціями, невміння здійснювати емоційну саморегуляцію (Новак О., 2010).

Було встановлено закономірність: рівень емоційного інтелекту вчителя залежить від педагогічного стажу, тобто чим більший стаж роботи в школі, тим вища здатність ідентифікувати власні емоції та переживання, тобто емоційний інтелект розвивається під впливом життєвого та професійного досвіду (там само).

За дослідженнями М. Манойлової, найбільш улюблені учнями й найбільш професійно продуктивні вчителі краще обізнані, порівняно з іншими педагогами, з такими емоційними властивостями особистості, як емпатія, толерантність, тактовність, і вважають їх необхідними для своєї професійної діяльності. У процесі комунікативної взаємодії вони поводяться впевнено і з повагою сприймають позицію співрозмовника. У них висока та адекватна самооцінка, високі рівні особистої відповідальності та емоційної стабільності, розвинений потяг до нового; вони не залежні від думки групи, вирізняються добре розвиненим самоконтролем. М. Манойлова вважає, що саме емпатія, відповідальність, самооцінка і самоконтроль є системоутворювальним центром професійної продуктивності вчителя і саме вони є базовими складовими емоційного інтелекту. Справедливість такого висновку було підтверджено за допомогою опитування учнів молодших і старших класів (Манойлова М., 2004).

Серед особистісних якостей, за які учні люблять своїх учителів, пріоритети надано емоційно-комунікативним та емпатійним, а саме: веселості, доброзичливості, чуйності, ввічливості, справедливості, повазі, доброті, а також упевненості, відповідальності, рішучості, витримці.

Отже, важливість високорозвиненого емоційного інтелекту для успішної професійної діяльності та недостатній рівень сформованості його основних компонентів у вчителів зумовлюють необхідність наполегливої роботи 3 його подальшого розвитку в усіх суб'єктів освітнього процесу, у тому числі й учителів. Таке навчання для вчителів початкової школи повинно стати внутрішньою потребою.

Спираючись на положення теорії емоційного інтелекту, науковці почали визначати особливості емоційного інтелекту фахівців різних професій, щоб з'ясувати функціональне спрямування кожного компонента його структури і зрозуміти, від чого саме залежатиме успіх професіонала. Своє розуміння досліджуваної проблеми науковці презентували за допомогою моделювання відповідного образу, що надавало можливість з'ясовувати змістове наповнення кожного компонента емоційного інтелекту окремо.

Модель емоційного інтелекту - це лише об'єкт для теоретичного пізнання, що не має аналога в чуттєвому світі. Предмет дослідження в моделі відтворюється ідеально, тобто в мисленні на рівні ідеї. Саме із створення таких ідеальних об'єктів і починається теоретичний рівень дослідження, оскільки вони дають можливість встановити не лише причинові зв'язки, але й глибше проникнути в сутність явищ, зрозуміти внутрішній механізм цих зв'язків.

Своє бачення моделі емоційного інтелекту педагога оприлюднили І. Андрєєва, С. Дерев'янко, Н. Манойлова, Е. Почтарьова та інші.

І. Андрєєва називає емоційний інтелект учителя «емоційною грамотністю», рівень якої залежить від цілеспрямованого підвищення емоційної культури. Найбільш значущими для професійної взаємодії елементами його структури вважає вміння керувати власними емоціями й розуміти емоції оточуючих. Досліджуючи особливості професійної діяльності вчителів, науковець виокремила в структурі емоційного інтелекту педагогів такі обов'язкові компоненти:

- емоційну обізнаність як можливість за ознаками вербальної та невербальної поведінки розуміти емоційний стан інших людей;

- керування власними емоціями, тобто вміти визначати детермінанти появи тої чи тої емоції та ймовірні наслідки її розвитку, знаходження способів регулювання емоційних станів;

- самомотивацію, тобто вміння ефективно діяти й приймати рішення на основі емоцій;

- емпатію як здатність розуміти почуття іншої людини й співчувати їй (Андреева І., 2008).

Не дуже відрізняються й групи особистісних якостей учителя, важливі для успішної професійної діяльності, виокремлені Ю. Кулюткіним та Т. Сухобською, а саме:

- емпатія як здатність розуміти емоційний настрій, почуття іншої людини, відгукуватися на них і співпереживати;

- динамізм особистості як здатність активно впливати на учнів за допомогою своєї внутрішньої енергії, ініціативності, вольових педагогічних впливів, винахідливості, гумору й організаційних здібностей;

- здатність до саморегуляції, емоційна стійкість, що виявляються в терпимості та наполегливості, витримці в стресових ситуаціях (Мышление учителя, 1990).

М. Манойлова найважливішими елементами структури емоційного інтелекту вчителя вважає емоційнокомунікативні та регулятивні здібності (Манойлова, 2004).

Е. Почтарьова позиціонує емоційний інтелект учителя як важливу складову його неперервної освіти і наголошує на розвитку емоційного інтелекту у взаємозв'язку з педагогічною творчістю, що забезпечує 
продуктивно-творчий характер професійно-педагогічної діяльності та попереджає синдром психоемоційного вигорання (Почтарева Е., 2011).

М. Голубєва характеризує емоційний інтелект як емоційну креативність вчителя, тобто здатність оригінально, нестандартно виявляти в різних аспектах професійної діяльності власний емоційний ресурс, емоційно-комунікативні здібності: емпатію, комунікативну толерантність, такт, альтруїзм, створення позитивного емоційного фону у спілкуванні з іншими, подолання усталених негативних настанов (Голубева М., 2013).

Незважаючи на розбіжності в трактуванні змісту та компонентів емоційного інтелекту вчителів, науковці спільні в думці про те, що це інтегроване динамічне утворення, структуру якого складають емоційний, когнітивний та діяльнісний компоненти, що в єдності забезпечують вимоги педагогічної професії, її гуманістичної сутності.

\section{ВИСНОВКИ ТА ПЕРСПЕКТИВИ ПОДАЛЬШИХ ДОСЛІДЖЕНЬ}

Отже, нормативні освітянські документи та висновки з наукових досліджень щодо того, які елементи емоційного інтелекту є базисними для професійних компетентностей учителя початкової школи, в основному, збігаються, оскільки наголошується на значущості для педагогічної діяльності таких особистісних якостей і складових емоційного інтелекту, як емпатія, здатність до саморегуляції, комунікативність. Справа за тим, щоб учителі могли визначити свої психолого-емоційні проблеми і спроєктували власну програму професійноособистісного зростання.

\section{СПИСОК ВИКОРИСТАНИХ ДЖЕРЕЛ}

Андреева, И. Н. (2008). Об истории развития понятия «эмоциональный интеллект». Вопросы психологии, 5.

Вайсбах, Х., Дакс, У. (1998). Эмоциональний интеллект. Душа и тело. Лик пресс.

Гарскова, Г. (1999). Введение понятия «эмоциональный интеллект» в психологическую теорию. Ананьевские чтения - 99: тезисы научно-практической конференции. Санкт-Петербург.

Голубева, М. (2013). Психологические условия и сопровождение развития емоциональной креативности студентов педагогических спеціальностей: автореф. дис.... канд. псих. наук. (19.00.07). URL: https://www.dissercat.com/content/ psikhologicheskie-usloviya-i-soprovozhdenie-razvitiya-emotsionalnoi-kreativnosti-studentov- $\mathrm{p}$

Ґоулман, Д. (2019). Емоційний інтелект. Харків, Віват. URL: http://booksonline.com.ua/ view.php?book=51983

Журавльова, М. (без дати). Емоційний інтелект як проблема психологічних досліджень. URL: https://scienceandeducation.pdpu.edu.ua/ doc/2009/1_2_2009/14.pdf.pdf

Ильин, Е. (2017). Эмоции и чувства: СПб : Питер. URL: http://www.alleng.ru/d/psy/psy036.htm

Люсин, Д. (1996). Организация знаний об эмоциях: внутренняя структура категории «эмоция». Познание, общество, развитие / под ред. Д.В. Ушакова. Москва : Институт психологии РАН.

Манойлова, М. (2004). Акмеологическое развитие емоционального интеллекта учителей и учащихся. Псков: ПГПИ. URL: http:// window.edu.ru/resource/127/22127/files/ pspu041.pdf

Мышление учителя: Личностные механизмы и понятийный аппарат (1990). Под ред. Ю.Н. Кулюткина, Г.С. Сухобской. М.: Педагогика.

Новак, О. (2010). Шляхи розвитку емоційного інтелекту педагогічних працівників. Постметодика, 6 (97), 41-47. URL: http://www.irbisnbuv.gov.ua/cgi-bin/irbis_nbuv/cgiirbis_64.exe?|21DBN=LINK\&P21DBN=UJRN\&Z21ID=\&S21REF=10\&S21CNR=20\&S21STN=1\& S21FMT=ASP_meta\&C21COM=S\&2_S21P03=FILA=\&2_S21STR=Postmetodyka_2010_6_8

Почтарева, Е. (2011). Эмоциональный интеллект как составляющая непрерывного образования педагога. Научное обеспечение системы повышения квалификации кадров, 2 (11).

Професійний стандарт «Учитель початкових класів закладу загальної середньої освіти» (без дати). URL: http://education-ua.org/ua/ tsifri-i-fakti/1230-profesijnij-standart-vchitel-pochatkovikh-klasiv-zakladu-zagalnoji-serednoji-osviti

Типова освітня програма для підвищення кваліфікації педагогічних працівників. (2018). URL: https://mon.gov.ua/ua/npa/prozatverdzhennya-tipovoyi-osvitnoyi-programi-organizaciyi-i-provedennya-pidvishennya-kvalifikaciyi-pedagogichnih-pracivnikivzakladami-pislyadiplomnoyi-pedagogichnoyi-osviti

Шпак, М. (2011). Емоційний інтелект у контексті сучасних психологічних досліджень . Психологія особистості, 1, 282-288. URL: http:// nbuv.gov.ua/UJRN/Po_2011_1_36

Шпак, М. (2017). Емпіричне дослідження психологічних особливостей розвитку емоційного інтелекту в молодшому шкільному віці. Психологічні перспективи, 29, 234-244.

Mayer, J., Salovey, P. (1993). The Intelligence of emotional intelligence. Intelligence, 17/4.

\section{REFERENCES}

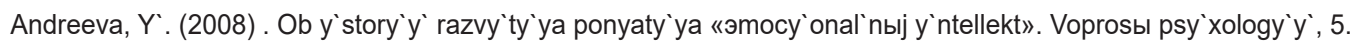

Vajsbax, X., Daks, U. (1998). Эmocy`onal'ny`j y’ntellekt. Dusha y’ telo. Ly’k press.

Garskova, G. (1999). Vvedeny`e ponyaty`ya «эmocy`onal’nыj y`ntellekt» v psy`xology`cheskuyu teory`yu. Anan`evsky`e chteny`ya - 99: tezy`sы nauchno-prakty'cheskoj konferency'y'. Sankt-Peterburg.

Golubeva, M. (2013). Psy'xology'chesky'e uslovy'ya y' soprovozhdeny`e razvy`ty`ya emociy’onal'noj kreaty 'vnosty' studentov pedagogy'chesky'x special'nostej: avtoref.dy's.... kand..psy'x.nauk. (19.00.07). Retrieved from https://www.dissercat.com/content/ psikhologicheskie-usloviya-i-soprovozhdenie-razvitiya-emotsionalnoi-kreativnosti-studentov-p

G’oulman, D. (2019). Emocijny`j intelekt. Xarkiv, Vivat. Retrieved from http://booksonline.com.ua/view.php?book=51983

Zhuravl’ova, M. (bez daty'). Emocijny`j intelekt yak problema psy'xologichny`x doslidzhen`. Retrieved from https://scienceandeducation.pdpu.edu. ua/doc/2009/1_2_2009/14.pdf.pdf

Y'I'y’n, E. (2017). Эmocy`y” y’ chuvstva: SPb: Py`ter. Retrieved from http://www.alleng.ru/d/psy/psy036.htm

Lyusy`n, D. (1996). Organy`zacy`ya znany`j ob эmocy`yax: vnutrennyaya struktura kategory 'y” "эmocy`ya». Poznany`e, obshhestvo, razvy`ty`e / pod red. D.V. Ushakova. Moskva: Y'nsty`tut psy`xology`y` RAN. 
Manojlova, M. (2004). Akmeology`cheskoe razvy`ty`e emocy`onal'nogo y’ntellekta uchy`telej y` uchashhy`xsya. Pskov: PGPY`. Retrieved from http://window.edu.ru/resource/ 127/22127/files/pspu041.pdf

Mыshleny`e uchy 'telya: Ly`chnostnыe mexany`zmы y` ponyaty”jnыj apparat (1990). Pod red. Yu.N. Kulyutky`na, G.S. Suxobskoj. M.: Pedagogy`ka. Novak, O. (2010). Shlyaxy` rozvy'tku emocijnogo intelektu pedagogichny`x pracivny`kiv. Postmetody'ka, 6 (97), Retrieved from http://www.irbisnbuv.gov.ua/cgi-bin/irbis_nbuv/cgiirbis_64.exe?!21DBN=LINK\&P21DBN=UJRN\&Z21ID=\&S21REF=10\&S21CNR=20\&S21STN=1\&S21F MT=ASP_meta\&C21COM=S\&2_S21P03=FILA=\&2_S21STR=Postmetodyka_2010_6_8

Pochtareva, E. (2011). Эmocy’onal'nыj y'ntellekt kak sostavlyayushhaya neprerbivnogo obrazovany’ya pedagoga. Nauchnoe obespecheny’e sy’stemы povыsheny’ya kvaly'fy'kacy'y” kadrov, 2 (11).

Profesijny”j standart «Uchy`tel` pochatkovy`x klasiv zakladu zagal’noyi seredn`oyi osvity`» (bez daty`). Retrieved from http://education-ua.org/ua/ tsifri-i-fakti/1230-profesijnij-standart-vchitel-pochatkovikh-klasiv-zakladu-zagalnoji-serednoji-osviti

Ty pova osvitnya programa dlya pidvy’shhennya kvalifikaciyi pedagogichny'x pracivny'kiv. (2018). Retrieved from https://mon.gov.ua/ua/npa/prozatverdzhennya-tipovoyi-osvitnoyi-programi-organizaciyi-i-provedennya-pidvishennya-kvalifikaciyi-pedagogichnih-pracivnikiv-zakladamipislyadiplomnoyi-pedagogichnoyi-osviti

Shpak, M. (2011). Emocijny`j intelekt u konteksti suchasny`x psy`xologichny`x doslidzhen`. Psy`xologiya osoby`stosti, 1, 282-288. Retrieved from http://nbuv.gov.ua/UJRN/ Po_2011_1_36

Shpak, M. (2017). Empiry 'chne doslidzhennya psy'xologichny'x osobly`vostej rozvy`tku emocijnogo intelektu $v$ molodshomu shkil'nomu vici. Psy`xologichni perspekty`vy', 29, 234-244.

Mayer, J., Salovey, P. (1993). The Intelligence of emotional intelligence. Intelligence,17/4. 